www.jmscr.igmpublication.org

Impact Factor 3.79

ISSN (e)-2347-176x

crossref DOI: _http://dx.doi.org/10.18535/jmscr/v3i10.11

Journal Of Medical Science And Clinical Research

IGM Publication

An official Publication of IGM Publication

\title{
Assessing the Prognostic Significance of Fuhrman Grading in Renal Cell Carcinoma by Comparing with Morphological Prognostic Factors
}

Authors

Vissa Shanthi M.D ${ }^{1}$, Nandam Mohan Rao, M.D ${ }^{2}$, Byna Syam Sundara Rao, M.D ${ }^{3}$, Bhavana Grandhi, M.D ${ }^{4}$, Muram Reddy Vijaya Lakshmi, M.D

${ }^{1}$ Associate Professor, Department of Pathology, Narayana medical College, Nellore

Email: santhijp@gmail.com

${ }^{2}$ Associate Professor, Department of Pathology, Narayana medical College, Nellore

Email:nmr2020kmc@gmail.com

${ }^{3}$ Associate Professor, Department of Pathology, Narayana medical College, Nellore

Email: syam.byna@gmail.com

${ }^{4}$ Assistant Professor, Department of Pathology, Narayana medical College, Nellore Email:drbhavana.grandhi@gmail.com

${ }^{5}$ Assistant Professor, Department of Pathology, Narayana medical College, Nellore

Email: vishmi_reddy@yahoo.co.in

Corresponding Author

Dr V. Shanthi

Flat no. 301, Anjani SVGK Towers, Sri Hari nagar, Ramalingapuram, Nellore, Andhra Pradesh, India

Email: santhijp@gmail.com, Phone no.-9849052179

\begin{abstract}
Back ground - Renal cell carcinoma is a disease of varying prognosis. We evaluated the prognostic significance of Fuhrman nuclear grade by comparing with various morphological parameters which are considered to be independent prognostic factors in determining the patient outcome.

Materials and methods - Retrospective and prospective study was conducted on patients who underwent nephrectomy during the period of January 2010 to June 2015. 128 cases of nephrectomies were studied out of which 32 cases had renal cell carcinomas which were studied in detail. Fuhrman grade of these tumors were compared with various morphological prognostic factors like tumor subtype the tumor size, tumor multicentricity, presence of sarcomatoid differentiation, necrosis, perinephric fat infiltration, lymph node metastasis, distant metastasis and vascular invasion by tumor.

Results - Out of 128 cases of nephrectomies, 32 cases had renal cell carcinomas. Male predominance was noted (68.75\%) in these cases. Fuhrman grade in these tumors were found to have correlation with prognostic factors like tumor stage, tumor size, presence of tumor necrosis, perinephric fat infiltration, vascular embolization, lymphnode metastasis. No significant correlation was found between the tumor grade and multicentricity.

Conclusion - Fuhrman nuclear grading is considered to be independent prognostic factor in renal cell carcinomas which determines the patient outcome.

Keywords: kidney tumors, Fuhrman grade, prognostic factors.
\end{abstract}




\section{Introduction}

Renal cell carcinoma represents the $7^{\text {th }}$ and $9^{\text {th }}$ most common malignancy in the men and women respectively in the United States and account for about $3 \%$ of cancer death ${ }^{(1)}$. The highest incidence of renal cell carcinomas occurred in Europe, North America, New Zealand and Australia. Lower rates were noted in the Pacific, Africa and Asia ${ }^{(2)}$.

Though the tumor stage is considered to be an important prognostic factor, assessing histological grade is important in evaluating the biological aggressiveness of a tumor ${ }^{(3)}$. Grading of tumors depending on the nuclear morphology was first proposed by Skinner. Later Syrjanen proposed another four-grade classification depending on the 4 criteria i,e. mitotic figure, anisonucleosis, nucleoli and chromatin distribution. In 1982, Skinner grading system was simplified by Fuhrman, who proposed four grade system depending upon tumor cell nuclear features like shape, size and nuclear contents ${ }^{(4)}$.

\section{Material and methods}

From January 2010 to June 2015, 128 patients who underwent radical nephrectomy in our institution were studied. Out of 128 cases, 39 cases had renal tumors and remaining 89 cases had non-neoplastic lesions. After obtaining the ethical committee approval, data of the patients with renal cell carcinomas were evaluated. Inclusion criteria in our study was histopathologycally confirmed renal cell carcinomas in surgically resected kidney specimen. Exclusion criteria in our study were histopathologically confirmed benign lesions and malignant lesions other than renal cell carcinomas like transitional cell carcinomas and lymphomas. The weight of the specimen and the tumor size was recorded on receiving the specimen. The staging of the tumor was done according to American Joint Committee on cancer TNM staging of renal cell carcinoma. Sections from the specimen were stained by Haematoxylin and Eosin. All the tumors were defined by their predominant cell types and nuclear grade was assigned by using Fuhrman grading criteria. Fuhrman criteria for grading the tumors is as follows: Grade I- tumor cells with small $(10 \mu \mathrm{m})$ uniform, round nuclei and with inconspicuous or absent nucleoli, Grade II- tumor cells with larger nuclei $(15 \mu \mathrm{m})$ with irregular nuclear membrane outline and with nucleoli visible under high power (X400), Grade III- tumor cells had larger nuclei $(20 \mu \mathrm{m})$ with irregular outlines and prominent nucleoli at low power (X100), Grade IV - tumor resemble grade III tumors but with multilobated, bizarre nuclei and with clumped chromatin. Nuclear grades were compared with various morphological prognostic factors like tumor stage, tumor size, presence of tumor necrosis, perinephric fat infiltration, vascular embolization, lymphnode metastasis. No significant correlation was found between the tumor grade and multicentricity.

\section{Results}

128 patients who attended nephrology OP and underwent nephrectomy in Narayana Medical College and Hospital, Nellore were studied. Out of these 128 cases, 89 had non-neoplastic lesions and 39 cases had neoplastic lesions (Table-1).

Out of 39 cases of neoplastic lesions, 5 cases had benign lesions. 4 cases were of Angiomyolipomas and one case was of mesoblastic nephroma. 34 cases had malignant neoplasms, out of which 32 had renal cell carcinoma, one case was papillary transitional cell carcinoma and another was renal lymphoma (Table-2).

32 cases of renal cell carcinoma were studied in detail. Maximum number of cases were in males (Table-3). Most of the tumors were in the age group of 40-59 years (Table -4).

Different subtypes of renal cell carcinomas were studied and maximum number of cases in our study were clear cell type $(50 \%)$ (Table -5$)$.

To study the prognostic importance of nuclear grading all the tumors are divided into 4 grades depending on the Fuhrman nuclear grading criteria. 7 cases were of grade 1, 14 cases were of 
grade 2 and 11 cases were of grade 3 . No tumor was in grade 4. The grades of the tumor are compared with different morphologic prognostic factors.

When the grade of tumors were compared with tumor stage, maximum number of stage 1 tumors were of grade 2, stage II tumors were of grade 2 and 3, stage III tumors were of grade 2 and 3 and two cases of stage 4 tumors were of grade 4 (Table 6).

The tumor grade and size was compared, which showed maximum number of cases with less than $4 \mathrm{cms}$ were of grade 1 and grade 2, 4-7cms size tumors were in grade 2 and more than $7 \mathrm{cms}$ size tumors were of grade 2 and grade 3 (Table 7). On comparision of the tumor grade and lymph nodal metastasis, maximum number of grade 3 tumors showed lymphnodal metastasis (Table 8).
Sarcomatoid differentiation was noted in 7 cases out of which 4 cases were of grade 3 (Table 9). Renal vessel involvement was noted in 11 cases and maximum number of cases were of grade 3 (Table 10). 20 cases showed necrosis. 6 cases showed necrosis in less than $50 \%$ of tumor and 14 cases showed necrosis in more than $50 \%$ of tumor and more number of cases were of grade 3 (Table-11). Perinephric fat infiltration was noted only in 6 cases out of which 4 cases were of grade 3 (Table 12). No tumor showed multicentricity in our study.

Though all the morphological parameters did not show significant statistical relationship due to low number of cases, grade 3 tumors showed worse morphological prognostic factors when compared to other grade tumors.

Table 1- Frequency of non-neoplastic and neoplastic lesions

\begin{tabular}{|ll|}
\hline LESIONS & NUMBER OF CASES \\
\hline Non-neoplastic & $89(69.53 \%)$ \\
\hline Neoplastic & $39(30.47 \%)$ \\
\hline Total & 128 \\
\hline
\end{tabular}

Table 2- Types of neoplastic lesions in kidney

\begin{tabular}{|ll|} 
Lesion & Number of cases \\
Angiomyolipoma & 5 \\
Mesoblastic nephroma & 4 \\
\hline Malignant lesions & 1 \\
Papillary transitional cell carcinoma & 34 \\
Malignant lymphoma & 1 \\
Reanl cell carcinoma & 1 \\
\hline
\end{tabular}

Table-3 - Sex distribution in cases of RCC

\begin{tabular}{|ll|} 
Sex & Number of cases \\
\hline Males & $22(68.75 \%)$ \\
\hline Females & $10(31.25 \%)$ \\
\hline
\end{tabular}

Table -4: Incidence of Renal cell carcinoma in different age groups

\begin{tabular}{|ll|}
\hline Age group in years & Number of cases \\
\hline $0-19$ years & - \\
\hline $20-39$ years & $2(6.25 \%)$ \\
\hline $40-59$ years & $22(68.25 \%)$ \\
\hline $60-79$ years & $8(25 \%)$ \\
\hline 80 years and above & - \\
\hline
\end{tabular}


Table 5: Incidence of different subtypes of Renal cell carcinoma

\begin{tabular}{|ll|}
\hline Subtypes of RCC & Number of cases $(\mathrm{n}=32)$ \\
\hline Clear cell type & $16(50 \%)$ \\
\hline Papillary type & $10(31.25 \%)$ \\
\hline Chromophobe type & $4(12.5 \%)$ \\
\hline Collecting Duct type & $2(6.25 \%)$ \\
\hline Undifferentiated & - \\
\hline
\end{tabular}

Table 6- Comparison between the tumor grade and stage of the tumor

\begin{tabular}{|lllll|}
\hline & Stage I $(n=20)$ & Stage II $(n=4)$ & Stage III $(n=6)$ & Stage IV $(n=2)$ \\
\hline Grade 1 & 7 & - & - & - \\
\hline Grade 2 & 9 & 2 & 3 & - \\
\hline Grade 3 & 4 & 2 & 3 & 2 \\
\hline Grade 4 & - & - & - & - \\
\hline
\end{tabular}

Table 7 - Comparison between the tumor grade and tumor size

\begin{tabular}{|llll|} 
& $<4 \mathrm{cms}$ & $4-7 \mathrm{cms}$ & $>7 \mathrm{cms}$ \\
\hline Grade 1 & 3 & 4 & 2 \\
\hline Grade 2 & 3 & 9 & 2 \\
\hline Grade 3 & 2 & 7 & - \\
\hline Grade 4 & - & - & \\
\hline
\end{tabular}

Table 8 - Comparison between tumor grade and lymphnode metastasis

\begin{tabular}{|lll|} 
& $\begin{array}{l}\text { Lymphnode metastasis } \\
\text { Present }\end{array}$ & $\begin{array}{l}\text { Lymphnode metastasis } \\
\text { Absent }\end{array}$ \\
\hline Grade 1 & 1 & 6 \\
\hline Grade 2 & 3 & 11 \\
\hline Grade 3 & 8 & 3 \\
\hline Grade 4 & - & - \\
\hline
\end{tabular}

Table 9 - Comparison between tumor grade and sarcomatoid differentiation

\begin{tabular}{|lll|} 
& $\begin{array}{l}\text { Sarcomatoid differentiation } \\
\text { Present }\end{array}$ & $\begin{array}{l}\text { Sarcomatoid differentiation } \\
\text { Absent }\end{array}$ \\
\hline Grade 1 & 0 & 7 \\
\hline Grade 2 & 3 & 11 \\
\hline Grade 3 & 4 & 7 \\
\hline Grade 4 & - & - \\
\hline
\end{tabular}

Table 10- Comparison between tumor grading and renal vessel involvement

\begin{tabular}{|lll|} 
& Vessel involvement & Vessel involvement \\
& Present & Absent \\
\hline Grade 1 & 0 & 7 \\
\hline Grade 2 & 5 & 9 \\
\hline Grade 3 & 6 & 5 \\
\hline Grade 4 & - & - \\
\hline
\end{tabular}


Table 11 - Comparison between tumor grade and presence of necrosis

\begin{tabular}{|llll|} 
& Necrosis absent & Necrosis in $<50 \%$ & Necrosis in $>50 \%$ \\
\hline Grade 1 & 7 & - & - \\
\hline Grade 2 & 3 & 5 & 6 \\
\hline Grade 3 & 2 & 1 & 8 \\
\hline Grade 4 & - & - & - \\
\hline
\end{tabular}

Table 12 - Comparision of tumor grade and perinephric fat infiltration

\begin{tabular}{|lll|l|} 
& $\begin{array}{l}\text { Perinephric fat infiltration } \\
\text { present }\end{array}$ & $\begin{array}{l}\text { Perinephric fat infiltration } \\
\text { absent }\end{array}$ & 7 \\
\hline Grade $1(n=7)$ & - & 12 \\
\hline Grade $2(n=14)$ & 2 & 7 \\
\hline Grade $3(n=11)$ & 4 & \\
\hline Grade 4 & & & \\
\hline
\end{tabular}

\section{Discussion}

In our study, we evaluated the use Fuhrmans nuclear grading in assessing the prognosis of renal cell carcinomas. Though the TNM staging is the most important prognostic factor in assessing the tumor prognosis, the prognosis of intracapsular renal cell carcinoma is not predictable. For the intracapsular tumors, TNM staging uses the size of the tumor as the most reliable prognostic factor. Along with the size of the tumor, assessing the nuclear grade of the tumor will act as important predictor of the patient outcome.

It has been suggested that the grading of tumor by using nuclear criteria is a better prognostic indicator than any other systems used ${ }^{(5)}$. In the study done by Medeiros et al, grading done by nuclear criteria was reported to be significant prognostic factor when compared to greatest tumor dimension.

Fuhrman et al in 1982 described the nuclear criteria for grading renal cell carcinomas. Grading was done on the microscopic morphological features of tumor cells in Haematoxylin and Eosin stained tissue sections. Conventional Fuhrman grading system which is currently validated for grading clear cell renal cell carcinoma categorizes the tumor into 4 grades. Grade 1: The nuclei of the tumor cells are smaller $(<10 \mu \mathrm{m})$, round, hyperchromatic with no visible nucleoli under 10X objective. Grade 2: The tumor cell nuclei is slightly larger $(15 \mu \mathrm{m})$ with finely granular open chromatin and a small inconspicuous nucleoli which is visible under higher power. Grade 3: The nuclei of tumor cells are still more larger $(20 \mu \mathrm{m})$ with coarsely granular chromatin and prominent nucleoli which is easily recognized under $10 \mathrm{X}$ objective. Grade 4: The nuclei are pleomorphic with irregular shape, with open chromatin or hyperchromatic and with single or many macronucleoli. In grades 1 and 2 tumors mitotic activity is rare or absent and is present in grades 3 and 4. Tumor is assigned a grade depending upon the highest grade present. Scattered tumor cells are not counted. But if the several cells in one high power field show higher grade then the tumor is assigned that grade. The majority of tumors in our study were in grade 2 and 3 when compared to grade 1 which coincided with study done by Grignon DJ et al ${ }^{(6)}$

As there were some interobserver variation in the Fuhrman grading system, further this system was simplified by some researchers to improve the reproducibility ${ }^{(7)}$. It has been demonstrated that prognostic ability of Fuhrman grading can be improved by using the three tiered system where Grades 1 and 2 are combined while grade 3 and 4 are kept separate ${ }^{(8)}$. 2 tiered grading system was introduced by Zisman et al who grouped conventional Fuhrman grade 1 and 2 into grade 1 and grouped the grade 3 and 4 into grade $2^{(9)}$. However, the 2 tiered and 3 tiered grading systems were compared with 4 tiered grading 
system by sun et al and he demonstrated that 2 tiered and 3 tiered grading system are equally valuable as 4 tiered Fuhrman grading system ${ }^{(10)}$. Even in predicting the cancer specific mortality, both 2 tiered and 4 tiered grading system have equal prognostic accuracy ${ }^{(11)}$.

\section{Conclusion}

Based on our study we concluded that the Fuhrman nuclear grading is important and independent prognostic factor in assessing the patient outcome. Though our study could not have statistical significance due to limited number of cases, the maximum tumors with higher grades showed renal vessel involvement, lymphnode metastasis, tumor necrosis, perinephric fat infiltration and sarcamotoid differentiation, demonstrating the prognostic importance of Fuhrman grading.

\section{References}

1. Jemal A, Siegal R, Ward E, Hao Y, Xu J, Thun MJ: Cancer statistics, 2009.CA Cancer J Clin.2009;59:225-49.

2. Parkin DM, Bray F, Ferlay J, Pisani P. Global cancer statistics, 2002. CA Cancer J Clin. 2005;55:74-108.

3. Marroncle M, Irani J, Dore B, Levillain P, Goujon JM, Aubert J. Prognostic value of histological grade and nuclear grade in renal adenocarcinoma. J Urol 1994;151:1174-6.

4. Denis Bretheau, Eric Leche Vallier, Marc de Fromont, Marie-Christine Sault, Mariur Ramphal, Christian Coulange. Prognostic value of nuclear grade of renal cell carcinoma. Cancer 1995; vol 76,No:12,2543-2549.

5. Medeiros LJ, Jones EC, Aizawa S, et al. Grading of renal cell carcinoma. Workgroup no.2. Cancer 1997;80:990991.

6. Grignon DJ, Ayala AG, el-Naggar A et al. Renal cell carcinoma. A clinicopathological and DNA flow cytometric analysis of 103 cases.Cancer 1989;64(10):2133-40.

7. Lang H, Linder V, de Fromont Molinie V, Letourneux $\mathrm{H}$, Meyer $\mathrm{N}$, Martin $\mathrm{M}$, Jacqmin D. multicentre determination of optimal interobserver agreement using the Fuhrman grading system for renal cell carcinoma: Assessment of 241 patients with >-15 year follow up. Cancer 2005;10:625-629.

8. Ficarra V, Martignoni G, Maffei N, Brunelli M, Novara G, Zanolla L, Pea M, Artibani N. Original and reviewed nuclear grading according to the Fuhrman system: a multivariate analysis of 388 patients with conventional renal cell carcinoma. Cancer 2005;103:68-75.

9. Zisman A, Pantuck AJ, DoreyF et al. Improved prognostication of renal cell carcinoma using an integrated staging system. J Clin Oncol 2001;19(6):1649-57.

10. Sun M, Lughezzani G, Jeldres C, et al. A proposal for reclassification of the Fuhrman grading system in patients with clear cell renal cell carcinoma. Eur Urol 2009;52(5):775-81.

11. Rioux -Leclercq N, Karakiewicz Pl, Trinh QD, Ficarra V, Cindolo L, de la Taille A, Tostain J, Zigeuner R, Mejean A, Patard JJ. Prognostic ability of simplified nuclear grading of renal cell carcinoma. Cancer 2007;109:868-874. 